Iveta Ubreziova,

Professor, Catholic University in Ruzomberok, Slovakia

ORCID ID 0000-0003-3681-1297

email: iveta.ubreziova@ku.sk, iubreziova@gmail.com

Anna Diacikova,

Ph.D., Catholic University in Ruzomberok, Slovakia

ORCID ID 0000-0002-0742-6122

email: anna.diacikova@ku.sk

Oksana Sokil,

Slovak University of Agriculture in Nitra, Slovakia

(iD) ORCID ID 0000-0002-8315-7403

email: oksana.sokil@gmail.com, xsokil@is.uniag.sk

Stefan Apostol,

State Agrarian University of Moldova, Moldova

iD ORCID ID 0000-0001-5341-6673

Correspondence author: iveta.ubreziova@ku.sk, iubreziova@gmail.com

\title{
INNOVATION ECOSYSTEMS FOR THE MOLDOVAN SMALL AND MEDIUM-SIZED ENTERPRISES
}

Abstract. In the last decades, the word 'innovation' can be heard more and more on the entrepreneurial side. It has a crucial role in satisfying the customers, competition with other companies, and increasing the turnover of the enterprises. SMEs economic performance is directly affecting the national budget. Still, there is not a precise method of assessing and improving the innovation process at neither firm nor national level. The paper aims to analyse the current innovative performance of Moldovan SMEs. The analysis will explore factors affecting enterprise innovation. It will determine how the existing innovation ecosystem affects the one in an enterprise, and what methods should be applied to improve innovation as well as the ecosystem. To gain insight, the study conducted an email survey of 150 companies, which were the object for research in the Republic of Moldova. The primary purpose of the study is to emphasise the importance of innovation issues related to increasing SMEs competitiveness, in connection with presenting the theoretical aspects in the field, proving basic concepts and quantifying them in the study of innovation as well as various forms, types and factors influencing innovative organisations. The objective of these enterprise questionnaires is to accumulate substantial and reliable information that is significant to responding to the fundamental research questions. Methodological tools of the research methods were the tools for statistical analysis based on using primary data from the questionnaire research. The reference period for statistical research was 2013 and 2017. The author collected the data between August and September 2018 based on questionnaires filled in on paper or sent through the email by the enterprises included in the research. The results of the study provide the following insights: product innovation is the primary innovation type among Moldovan SMEs; the country lacks financial resources for innovation support. Also, Moldova's weak innovation ecosystem and lack of highly qualified workers slow down the development of enterprises. At the end of the thesis, the several recommendations for enterprise managers as well as high-level government organisations were provided.

Keywords: ecosystems, entrepreneurs, innovation, small and medium-sized enterprises, SMEs, Moldova.

Introduction. In the last one hundred years, technological development advanced more than in the previous thousands or even million years. Globalisation and technological development have probably the leading roles in the social, scientific, medical and economic fields. Each day, new ideas, products and methods are created by companies. Small and medium-sized enterprises SMEs or large companies, in a particular niche or industry they are not alone, and they face a lot of challenges. To compete and maintain

Cite as: Ubreziova, I., Diacikova, A., Sokil, O., \& Apostol, S. (2020). Innovation Ecosystems for the Moldovan Small and Medium-Sized Enterprises. Marketing and Management of Innovations, 2, 298-312. http://doi.org/10.21272/mmi.2020.2-22 

Enterprises

the high market position, entrepreneurs are required to harness all possible means, first of all, related to human intellectual capabilities, such as creativity, agility to adapt quickly to the environment, constantly changing customer requirements and growing competition. A considerable number of companies claims that innovation has an essential role in business growth. However, also as a result of the implementation of innovative activities in organisations, not only the improvement of organisational performance takes place, especially new business opportunities emerge, strengthening the competitive advantage. It is necessary to take into consideration the theories of innovations as well as the application of product or technological innovations into practice from the works of several authors like (Halasi et al., 2019; Pitekova and Vrablikova,2019; Janoskova and Palascakova, 2018; Mura, 2017; Ubreziova et al., 2015; Ubreziova, A. and Horska, 2011). From the viewpoint of the main idea, the goal of the submitted paper is to evaluate the innovation process and the innovation ecosystems for the Moldovan small and medium-sized enterprises. On the other hand, the education background of the managers, business owners and entrepreneurs is an essential factor explaining innovation in organisations (Koellinger, 2008). Thus, the human element concerning motivation is one of the crucial factors for success. Most often, the critical reasons for implementing innovative management are: the desire of companies to gain competitive advantage, increase market share, conquer new markets, improve product quality, expand their range, increase business profitability, and certainly meet customer demand (Schwab, 2018; Chladkova and Formankova, 2016; Madzik, 2019). During recent years, a new economic system, the namely sharing economy has gained significant importance due to its impacts on economic, social and environmental issues. Its considerable influences make individuals and businesses to be interested in this new trend. Therefore, many new players and entrepreneurs come into existence in various industries based on Kljucnikov et al. (2020).

Literature Review. During several years, the time of innovation was associated with change despite the fact they are not the same. But from the definition point of view, an accident, event, insight or random event cannot be considered an innovation. Therefore, innovation should be connected to some related practical value brought to the world. In the entrepreneurial environment, the word "innovation" has been introduced the restoration and enlargement of new products and technologies concerning new markets, the original form of marketing communication, the creation of new methods of purchase, production and distribution, new managerial changes, labour organisation, working conditions and qualification of operating power, etc. (McGrath, 2012; Selman, 2002). According to the object and the degree of innovation, but also the purpose, innovation can be of some types. The first classification is related to the object of innovation (Cherroun, 2014; Ubreziova, I., Wach, K. \& Horvathova, J., 2008). In general, innovations can be taken into consideration from several innovative products. According to Mihalcova et al. (2020), the available example is the financial education should enable individuals to develop their decision-making competencies related to money, dealing with it as well as with the risks of its investment.

Service innovation comprises of new or significantly improved service concepts and offerings, irrespective of whether they are introduced by service or manufacturing companies. Besides it also could be explained as innovation in the service process, service infrastructure, customer processing, business models, commercialisation (sales, marketing, delivery), service productivity and hybrid forms of innovation serving several user groups in different ways simultaneously (The Smart Guide to Service Innovation, 2014). Process and technology innovation is also defined in the Oslo Manual (2005) and (OECD, 2005). The disruptive innovation is used mainly when the creation of a new market is necessary. Usually, innovation use is dramatic and often game-changing. The customer does not know the original product, and the traditional business usually fails to activate because the methods used in this new kind of business are unique. Sustaining innovation, seeks to improve existing products. Meaning, it does not create new markets or values, but instead merely develop existing ones (Disruptive and sustaining innovation, 2018).

On the other hand, sustainable innovation is used when the market is existing, but the actions proposed aim to improve the performance, create incremental changes, but also lower costs. The customers are 

Enterprises

already known, and definitely, traditional business methods work correctly. According to the strategy of innovation of the Republic of Moldova, one process of development of high-tech companies must be on several dimensions: support and stimulation to increase staff competence; implementing new technologies (both imported and internally developed); business development in global markets. Increased attention should be paid to the environmental aspect of the producers, which will ensure lasting sustainability (Cernei, 2011). We can find two different ways to increment financial yield inside an economy are to (I) increment the number of contributions to the useful procedure, or (II) considers better approaches to get more return from a similar number of sources of inputs. From that reason, an innovation ecosystem models the economic rather than the energy dynamics of the complex relationships that are formed between actors or entities whose functional goal is to enable technology development and innovation (Jackson, 2019). The innovation ecosystem factors include the material resources, the human capital and industry-university research institutes based on Jackson, (2019) as well as (Reiljan and Paltser, 2015; Fila and Kucera, 2015). The leading institutions that have indispensable roles in the innovation ecosystem are the research centre and universities. As written in (Jiao et al., 2016), universities are agents that generate and diffuse knowledge as well, as promote regional development through its connections with the socioeconomic environment. Overall, as the ecosystem moves forward, cooperation, coordination and collaboration will be critical. Current strategies and efforts at ecosystem development and reform tend to run in different directions and tend to be soloed between different groups of actors. There is also an issue with trust and collaboration between various groups of stakeholders. An overarching strategy focused on the development of the ecosystem and providing roles for all of the ecosystem stakeholders will provide the framework for more coordinated efforts to develop the ecosystem, ensuring support for innovators throughout their lifecycle. Improved means for consultation and sharing of needs and experiences will ensure that the needs of all stakeholders are taken into account. Finally, strengthened communities and efforts to build trust, both directly and by removing barriers, will facilitate collaboration between different actors, building up the networks that will support the process of ecosystem development.

Methodology and research methods. In the world of today, the era of artificial intelligence, technology, social communication, innovation and keeping up with the technological pace is a thing of high importance. In particular, the researchers have been looking to find the methods and the techniques to measure the innovation potential of the Republic of Moldova. The authors included not only personal research on an individual sample of small and medium enterprises but also statistics from the Moldovan National Institute for Statistics, Global Indexes for Innovation and European Union Statistics. The implementation of statistical research on innovation activity is an essential element of the alignment of the Republic of Moldova with the Community acquis in the field of statistics. Indicators on activity enterprise innovation are included in a series of normative acts approved by Government Decision no. 952 of 27.11.2013; Development strategy a Small and Medium Enterprises Sector for the years 2012-2020 approved by the Government Decision no. 685 from 13.09.2012; The National Statistical System Development Strategy 2016-2020 approved by Government Decision no. 1451 of 30.12 .2016 also based on Stratan et al. (2018). As the leading reference to innovation, the global innovation index will be analysed to understand the country's innovation capabilities and results. But also to see the importance of the human factor influence behind innovation that would be essential for future framing of policies and recommendations that help promote economic improvement but also and more productive innovation-business creative environments. One of the reasons will also be the fact that the global innovation index includes different indicators comparing to simple innovation ones that go much higher than the traditional ways of innovation such as the level of economic development, clusters, research and development, as well. The primary method was a questionnaire-based tool. The sample of enterprises to which email surveys were submitted is 150 units. One of the first criteria based on which the companies surveyed and included in the sample were identified as their accessibility, coupled with the availability of the persons representing the undertakings concerned, to respond to the requests for questionnaires. At the same 
time, the structure of the enterprises included in the sample attempted to reproduce the structure of the Moldovan enterprises, according to various criteria of their classification. The main questions addressed and indicators resulting from the statistical survey are:

1. General Company Information;

2. Basic Economic Information about the Company;

3. Organisational Innovations;

4. Market Innovations (Marketing Innovation);

5. Technology Innovations;

6. Innovations (goods and services);

7. Events and Costs related to Innovative Products and Processes;

8. Turnover from innovation activity for new products;

9. The "triple helix" model or creating the innovation ecosystem.

The objective of these enterprise questionnaires is to accumulate substantial and trustworthy information that is significant to responding to the fundamental research questions:

Q1 Approximately what percentage of the total turnover has been spent on Organizational Innovation by the enterprise in 2013-2017.

Q2 Your company has made over the last four years of significant innovation changes in the selected areas.

Statistical research includes businesses with economic activities: agriculture, administration public, education, health and social work, leisure and leisure activities, other activities services, activities of private households and businesses of extraterritorial organisations and bodies. To achieve the proposed objectives, specific categories of statistical indicators will be involved. Considering the quality of their estimators (come from a selection collectivity), the activities for checking the significance of the determined estimators will be associated here.

The simple linear correlation coefficient between variables (Pearson) measures the intensity of the linkage between two variables. In this case, the correlated variables will be represented by the values of the dependent variables and the independent ones expressed in absolute values, relative indicators of structure and intensity, as well as by encoded aspects, in the case of qualitative variables (verbally expressed). Besides, the significance of the deviation of the correlation indicators to zero will be tested (Obtulovic, 2004).

$$
\mathrm{r}=\frac{\mathrm{n} \sum \mathrm{x}_{\mathrm{i}} \mathrm{y}_{\mathrm{i}}-\sum \mathrm{x}_{\mathrm{i}}-\sum \mathrm{y}_{\mathrm{i}}}{\sqrt{\left[\mathrm{n} \sum \mathrm{x}_{\mathrm{i}}^{2}-\left(\sum \mathrm{x}_{\mathrm{i}}\right)^{2}\right]\left[\mathrm{n} \sum \mathrm{y}_{\mathrm{i}}^{2}-\left(\sum \mathrm{y}_{\mathrm{i}}\right)^{2}\right]}}
$$

The linear correlation coefficient can take values between -1 and +1 . It satisfies the inequalities $-1 \leq$ $r \leq 1$. The sign indicates the link type: the minus sign shows the reverse link, the plus sign indicates the direct link. The simple linear correlation coefficient is closer to 1 or -1 ; the correlation between rectilinear correlations is stronger. As the correlation coefficient approaches zero, the intensity of the link between the two variables decreases. In the case of $r=0$, the variables are linear or non-linear, and $r=1$ results in a functional dependence between the two variables.

$0 \leq \mathrm{r} \leq 0,2$, there is no significant link;

$0,2 \leq \mathrm{r} \leq 0,5$, there is a weak link;

$0,5 \leq \mathrm{r} \leq 0,75$, there is a medium intensity link;

$0,75 \leq r \leq 0,95$, there is a secure link;

$0,95 \leq r \leq 1$, there is a relatively deterministic (functional) link.

In the next step, in the event of the possibility of characterising the relationship between the factorial variables (xj) and the resultant variables (yj), the regression models for the two stages (primary and secondary) will be specified and analysed, in the form of: 


$$
y_{i}=f\left(x_{1}, \ldots, x_{j}, \ldots, x_{k}\right)+e
$$

Thus, dependence models specific to these functions will be rendered by the regression relations of the form:

$$
\widehat{y_{j}}=\widehat{b_{0}}+\widehat{b_{1}} x_{1}+\cdots+\widehat{b_{j}} x_{j}+\widehat{b_{k}} x_{k}
$$

where bj is the estimators of the dependence model parameters of the studied variables, expressing the change of the resulting variable to the transformation of the factorial variable. Student Statistics (Tstatistics).

$$
t_{\text {calc }}=\frac{\widehat{b_{j}}-b_{j}}{s_{\widehat{b_{j}}}}=\frac{\widehat{b_{j}}}{s_{\widehat{b_{j}}}}
$$

Under a certain significance threshold $a$, the assumption of the significant difference of zero of the regression coefficients will be accepted.

$\mathrm{R}_{\mathrm{y} \mid \mathrm{x}_{1}, \ldots \mathrm{x}_{\mathrm{k}}}=\sqrt{1-\frac{\sum\left(\mathrm{y}_{\mathrm{i}}-\mathrm{Y}_{\mathrm{x}_{1}, . . \mathrm{x}_{\mathrm{k}}}\right)^{2}}{\sum\left(\mathrm{y}_{\mathrm{i}}-\overline{\mathrm{y}}\right)^{2}}}$

with the meaning 0 (no link) $\leq \mathrm{R} \leq 1$ (functional link)

Durbin-Watson Test:

$\mathrm{DW}=\mathrm{d}=\frac{\sum_{\mathrm{i}=2}^{\mathrm{n}}\left(\widehat{\mathrm{e}_{1}}-\widehat{\mathrm{e}_{1-1}}\right)^{2}}{\sum_{\mathrm{i}=1}^{\mathrm{n}}\left(\widehat{\mathrm{e}_{1}}\right)^{2}}$

which tests the hypothesis of the existence or absence of autocorrelation statistical errors, significance 0 (maximum positive autocorrelation of errors) $\leq d \leq 4$ (maximum negative autocorrelation error); $d=2$. non-autocorrelated errors

Fisher Test:

$$
\mathrm{F}=\frac{\mathrm{S}_{\mathrm{reg}}^{2}}{\mathrm{~S}_{\mathrm{rez}}^{2}}=\frac{\mathrm{V}_{\mathrm{E}}}{\mathrm{V}_{\mathrm{R}}} \times \frac{\mathrm{n}-\mathrm{k}}{\mathrm{k}-1}
$$
$\mathrm{F}_{\mathrm{a} ; \mathrm{n}-\mathrm{k}-1}$

by which the overall quality of the regression model, with the rule of decision, is evaluated $\mathrm{F}_{\text {calc }}>$

Under a certain significance threshold $a$, the assumption of the satisfactory quality of the model will be accepted. The author collected the data between August and September 2018 based on questionnaires filled in on paper or sent through the email by the enterprises included in the research. The reference period for statistical analysis was 2013 and 2017, including value indices such as turnover, innovation costs, for which the reference period is 2016.

Results. Innovative business performance is in a continuous interdependence with a multitude of factors capable of boosting innovation activities or, on the contrary, hampering their harmonious development. In this context, the modern management practices of complex innovation processes unveil 

Enterprises

the need to improve methodological approaches to assessing innovative development continuously. For long times within enterprises, the importance and necessity of innovation were discussed, and it was considered as the most pressing concerns of each organisation and its role in the development and coordination of the market is inalienable. It is found that innovation activity has a crucial role in growth, survival and success of organisations (Tohidi, 2012). Moreover, increasing the competitiveness of enterprises by increasing the importance of innovation development has led to the need for a profound knowledge of the factors affecting innovative enterprise-level activity as well as identifying ways to increase the volume of innovation output. In this context, in line with innovation and sophistication factors, the technological readiness indicator closely associated with the innovation competitiveness of the country is included in the analysis. For this research, it is of high importance to analyse the signs of innovation that cover how the world sees Moldova's innovation potential, and innovation sophistication factors what innovation data says at the national level, but also an in-depth comparison of the data on firm-level and results about innovation impact. The analysis is composed of indicators included in the World Economic Forum the Global Competitiveness reports from 2012 to 2018, Global Innovation Index, National Statistical Office, but also a personal study of innovation on a sample of enterprises (Table 1).

Table 1. Research and Development (R\&D) Innovation Pillars of the Republic of Moldova

\begin{tabular}{|c|c|c|c|c|c|c|c|c|c|c|}
\hline \multirow{2}{*}{$\begin{array}{l}\text { Factors } \\
\text { R\&D Innovation pillar }\end{array}$} & \multicolumn{2}{|c|}{2013} & \multicolumn{2}{|c|}{2014} & \multicolumn{2}{|c|}{2015} & \multicolumn{2}{|c|}{2016} & \multicolumn{2}{|c|}{2017} \\
\hline & & & & & & & & & & \\
\hline Capacity for innovation & 2.7 & 134 & 3.0 & 128 & 3.4 & 115 & 3.5 & 124 & 3.4 & 119 \\
\hline $\begin{array}{l}\text { Quality of scientific research } \\
\text { institutions }\end{array}$ & 2.6 & 132 & 2.7 & 121 & 2.7 & 124 & 2.8 & 125 & 2.9 & 115 \\
\hline Company spending on R\&.D & 2.1 & 142 & 2.3 & 135 & 2.3 & 135 & 2.2 & 135 & 2.4 & 135 \\
\hline $\begin{array}{l}\text { University-industry collaboration } \\
\text { in R\&D }\end{array}$ & 2.7 & 129 & 2.7 & 124 & 2.7 & 123 & 2.5 & 133 & 2.7 & 121 \\
\hline $\begin{array}{l}\text { Government procurement of } \\
\text { advanced technology products }\end{array}$ & 2.5 & 139 & 2.7 & 127 & 2.5 & 134 & 2.2 & 136 & 2.5 & 130 \\
\hline $\begin{array}{l}\text { Availability of scientists and } \\
\text { engineers }\end{array}$ & 3.1 & 131 & 3.1 & 128 & 2.9 & 132 & 2.9 & 131 & 3.1 & 120 \\
\hline $\begin{array}{l}\text { Utility patent granted } \\
\text { applications/million population }\end{array}$ & 0.4 & 81 & 0.8 & 73 & 1.2 & 67 & 0.7 & 77 & 0.9 & 72 \\
\hline
\end{tabular}

Source: own processing based on secondary information from internet sources.

One of the first steps in analysing the innovation potential of the Republic of Moldova is the review of the Report from the World Economic Forum, which includes the score and the world rank of different pillars relevant for improving the innovation process. Looking at the innovation pillars in Research and Development (further R\&D), we observe that the utility of the granted patent applications has one of the best rankings, in 2017 the RM holds the 72nd position from 140 countries according to this factor. We can see that the capacity for innovation changes to a better place in the world during the period from 2013 to 2017, with the rank from 134 to 119. In Figure 1, we can see the representation of the main pillars for innovation, represented by the World Economic Forum according to the scores given by the indicators. As described from all the symbols, the capacity for innovation has a rating of 3.4. Considering the thing, that innovation affects a lot of economic and noneconomic variables like profits, productivity growth, job creation, but also life expectancy and environment that's why to observe the innovation indicators of the country it is of high importance not only to the SMEs but also investors and policymakers (Table 2). 
l., Ubreziova, A., Diacikova, O., Sokil, S. Apostol. Innovation Ecosystems for the Moldovan Small and Medium-Sized Enterprises

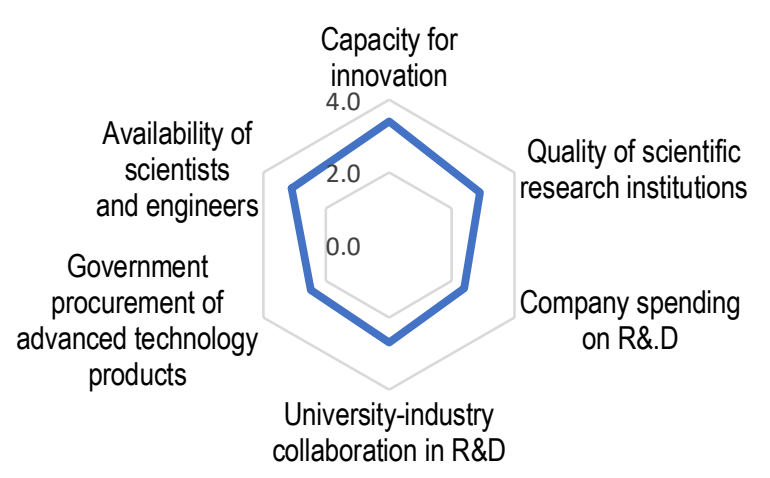

Figure 1. Representation of the most important factors for innovation and their development level Source: Prepared by the authors from the Global Competitiveness Report (2017)

The analysis of the structure of the innovative companies on their size classes allows observing that small enterprises have a share of $62 \%$. It will enable concluding that the lower the enterprise, the higher their innovative capacity, this can be caused by the fact that small companies are just launched on the market, so they should have a disruptive innovation to succeed. The new companies usually come on the market with a new product, so this can be another reason they have the highest innovation capacity. Medium enterprises with 50-249 Employees also have a high rate of innovation of $28 \%$, in comparison with the big companies with only $10 \%$. But these rates are also characterised by the thing that the SMEs have a higher standard in the share of total companies, but also in the amount of money SMEs participate in the gross domestic product. In industry, 319 SMEs with innovation activity $(52 \%$ of the total innovation SMEs) have activated, and in-services 290 SMEs (48\% of the total SMEs). The authors noticed that the number of innovative enterprises in services is higher in the capital city, and this decreases dramatically compared to the other regions where the number of manufacturing companies overcomes the number of service companies. As a part of their innovation activity, businesses have made product and process innovations through several development ways. Thus, in 2015-2016, $72 \%$ of the innovative enterprises of products created changes themselves, $14 \%$ - in cooperation with other enterprises, $7 \%$ - by adapting or modifying the products developed by different enterprises, $7 \%$ - elaborated by other businesses. In the case of innovative process enterprises, $52 \%$ developed self-innovation, $22 \%$ - in cooperation with other enterprises, $13 \%$ - by adapting or modifying processes developed by different enterprises, and $13 \%$ - by other enterprises. As a part of the cooperation on product and process innovation, $28 \%$ of innovative businesses indicated suppliers of equipment, materials, components or software to cooperate with partners, $26 \%$ - other businesses, $25 \%$ - customers or buyers, $13 \%$ and research institutions. According to the location of the cooperation partner, $70 \%$ of the innovative products and processes enterprises cooperated with Moldovan partners, 19\% - with partners in the European Union and 11\% - with partners from other countries. This structure tends to approach the general situation in the republic, starting in 2015, with a moderate deviation to the of private property, which in that year held a share of about $89.1 \%$.

The organisational-legal form is another criterion for the qualification of the enterprises, which implies a specific character in the economic and financial management of the enterprise. From this point of view, the sample covered the answers to this item, two, and at the same time, the most essential, organisationallegal forms - the limited liability companies and the joint-stock companies. The analysis of the distribution of enterprises in the sample allowed the average share reduction of enterprises to be reduced as the number of employees increased from 10 to 10 . 
I., Ubreziova, A., Diacikova, O., Sokil, S. Apostol. Innovation Ecosystems for the Moldovan Small and Medium-Sized Enterprises

Table 2. Technological readiness pillar of the R\&M and the influencing factors

\begin{tabular}{|c|c|c|c|c|c|c|c|c|c|c|}
\hline $\begin{array}{c}\text { Factors } \\
\text { Technological Readiness Pillar }\end{array}$ & \multicolumn{2}{|c|}{2013} & \multicolumn{2}{|c|}{2014} & \multicolumn{2}{|c|}{2015} & \multicolumn{2}{|c|}{2016} & \multicolumn{2}{|c|}{2017} \\
\hline $\begin{array}{l}\text { Availability of latest } \\
\text { technologies }\end{array}$ & 4.1 & 116 & 4.3 & 96 & 4.4 & 92 & 4.3 & 95 & 4.4 & 88 \\
\hline $\begin{array}{l}\text { Firm-level technology } \\
\text { absorption }\end{array}$ & 4 & 124 & 4.1 & 109 & 4.1 & 109 & 4 & 112 & 4 & 106 \\
\hline FDI and technology transfer & 4.1 & 109 & 4.2 & 97 & 4 & 99 & 3.9 & 100 & 4 & 98 \\
\hline Internet users \% pop. & 43.1 & 77 & 48.8 & 70 & 46.6 & 74 & 49.8 & 79 & 49 & 71 \\
\hline $\begin{array}{l}\text { Fixed-broadband Internet } \\
\text { subscriptions / } 100 \text { pop. }\end{array}$ & 11.9 & 52 & 13.4 & 52 & 14.7 & 52 & 15.5 & 56 & 16.3 & 54 \\
\hline Internet bandwidth $\mathrm{kb}$./s/user & 94 & 23 & 115.8 & 23 & 152 & 18 & 194.9 & 16 & 144 & 34 \\
\hline $\begin{array}{l}\text { Mobile-broadband } \\
\text { subscriptions / } 100 \text { pop. }\end{array}$ & 5.1 & 97 & 4.7 & 42 & 4.9 & 59 & 5.1 & 70 & 5.5 & 15 \\
\hline
\end{tabular}

Source: based on internet source Global Competitiveness Reports (2013-2017) and prepared by authors

Thus, in 2015, the average increase in the number of employees by ten persons led to a reduction in the share of enterprises by about 8,4 percentage points (pp), and the most recommended adjustment of this series is the logarithmic (Figure 2).

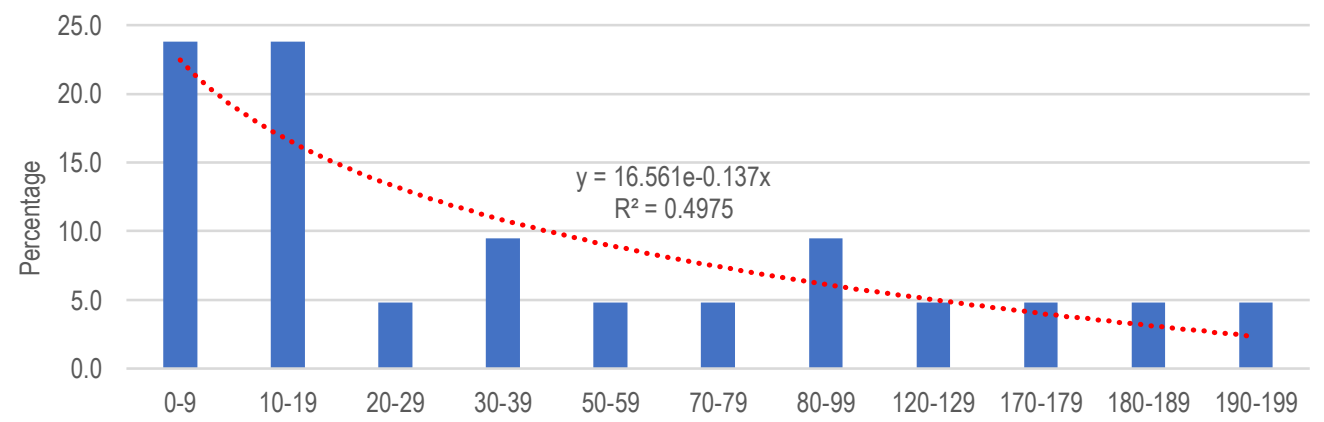

Figure 2. Distribution of enterprises surveyed by number of staff

Source: own processing by authors (2019).

The initiation of an innovation process is motivated by specific intentions, which overlap with certain factors identified to launch the decision to innovate. In this respect, several factors have been identified in some of the pilot studies that have been tested in the decision to innovate products or services and/or processes according to their importance. In the series of factors listed and ordered according to the importance given by the respondents, there is a visible increase in turnover, compliance with regulations and an increase in the market share, for which 17, 15 and 14 enterprises have opted for high and medium importance. The different number of respondents, who have put forward ratings in favour of /detracting from a particular factor, requires the operation of relative structural indicators. A first finding, which is highlighted, is that the average importance given to factors is much more frequent (the ordinary share of the average weight is $36.1 \%$ compared to the significant influence with a $26.2 \%$ share), which denotes a moderate attitude of the business environment towards the identified factors (Table 3). If the two higher categories of importance (large and medium) are combined, then the first factors favouring the decision to 
I., Ubreziova, A., Diacikova, O., Sokil, S. Apostol. Innovation Ecosystems for the Moldovan Small and Medium-Sized Enterprises

innovate can be the enumeration of profit growth, an increase of turnover and expansion of production capacity.

Table 3. Factors in the decision to innovate products or services and/or processes

\begin{tabular}{|c|c|c|c|c|c|c|c|c|c|c|}
\hline \multirow[b]{2}{*}{ No. } & \multirow[b]{2}{*}{ Factors } & \multicolumn{5}{|c|}{ No. of enterprises by the importance } & \multicolumn{4}{|c|}{ Structure of enterprises (\%) } \\
\hline & & High & Medium & Low & $\begin{array}{l}\text { Not } \\
\text { APL. }\end{array}$ & Total & High & $\begin{array}{l}\text { Mediu } \\
\mathrm{m}\end{array}$ & Low & $\begin{array}{l}\text { Not } \\
\text { APL.(\%) }\end{array}$ \\
\hline 1 & Increase in turnover & 12 & 22 & 4 & 6 & 44 & 27 & 50 & 9 & 14 \\
\hline 2 & Increase market share & 12 & 16 & 6 & 8 & 42 & 29 & 38 & 14 & 19 \\
\hline 3 & Cost reduction & 12 & 14 & 8 & 6 & 40 & 30 & 35 & 20 & 15 \\
\hline 4 & Profit growth & & 6 & 4 & & 10 & & 60 & 40 & \\
\hline 5 & $\begin{array}{l}\text { Increasing production } \\
\text { flexibility }\end{array}$ & 12 & 10 & 8 & 10 & 40 & 30 & 25 & 20 & 25 \\
\hline 6 & $\begin{array}{l}\text { Increasing production } \\
\text { capacity }\end{array}$ & 10 & 16 & 2 & 10 & 38 & 26 & 42 & 5 & 26 \\
\hline 7 & Increase value-added & 4 & 10 & 16 & 8 & 38 & 11 & 26 & 42 & 21 \\
\hline 8 & $\begin{array}{l}\text { Improving security } \\
\text { conditions }\end{array}$ & 12 & 12 & 6 & 16 & 46 & 26 & 26 & 13 & 35 \\
\hline 9 & $\begin{array}{l}\text { Compliance with } \\
\text { regulations }\end{array}$ & 14 & 16 & 8 & 6 & 44 & 32 & 36 & 18 & 14 \\
\hline & Average by importance & 11.0 & 13.6 & 6.9 & 8.8 & 40.19 & 26.4 & 37.6 & 20.1 & 21.1 \\
\hline
\end{tabular}

Besides, the order of elements, according to the accumulated shares, is as follows: Increase in profit $(60.0 \%)$, increase in turnover $(38.6 \%)$, improvement of production capacity $(34.2 \%)$, compliance with regulations $(34 \%)$, growth of the market share $(33.3 \%)$, cost reduction $(32.5 \%)$, an increase of the production flexibility $(27.5 \%)$, improvement of the security conditions $(26.1 \%)$, increase value-added (18.4\%). Therefore, among the most important factors motivating the decision to innovate are the factors expressing the results of the economic activity. However, the increase of the added value, which represents the newly created value, is surpassed exclusively by the other factors (18.4\%) (Figure 3 ).

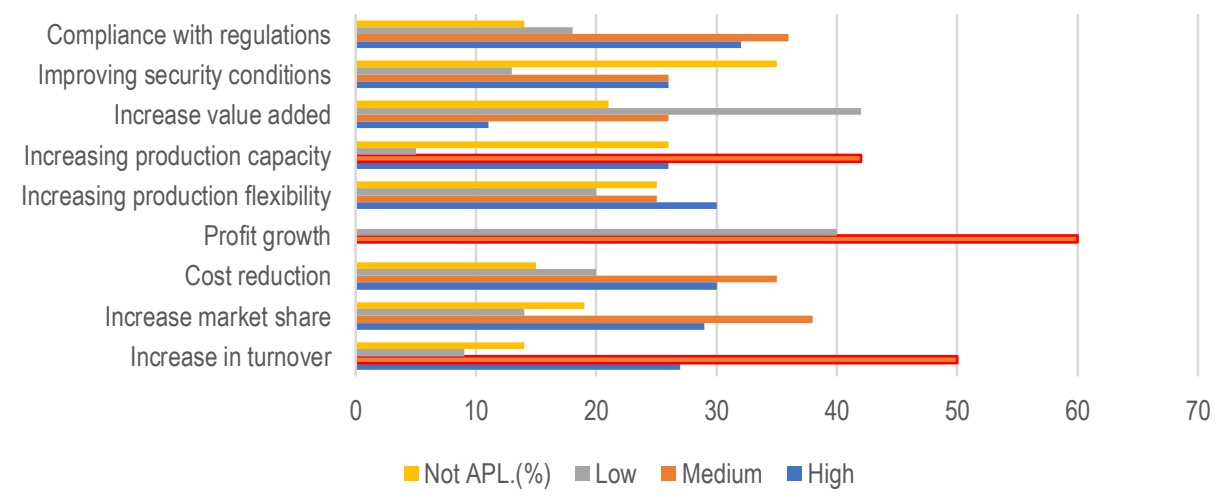

Figure 3. The odds of factors in the decision to innovate, according to the odds of importance Source: own processing on data from the questionnaire (2019). 
l., Ubreziova, A., Diacikova, O., Sokil, S. Apostol. Innovation Ecosystems for the Moldovan Small and Medium-Sized Enterprises

The data in Figure 3 shows the more impressive share of innovative activities, which imply the launch of significantly improved products or services on the market, which raises fewer maintenance difficulties in innovation activities. At very short distances, the weight of innovative enterprises of organisational and/or marketing methods and those who launched new products or services with 58.3 and $57.7 \%$ respectively, although these situations are more surprising and specific for the companies surveyed, and less for the political situation. In the same period, the enterprises under investigation registered, concerning process innovations, entirely consistent general performance, expressed by the average of the weight of the innovative process enterprises in the three categories. Thus, the total number of affirmative responses, including repeated interventions (when the enterprise has achieved several types of process innovation), based on the total number of replies (YES and NO), the determined performance of about $64.5 \%$. It assumes that $64.5 \%$ of the surveyed enterprises were innovative in terms of process innovation. From the theoretical and practical point of view, enterprises should be enabled to work also within the "triple helix" model. It is a model for the analysis of innovation in a knowledge-based economy. Mainly the cooperation between of these three innovation actors where the university motivates the students to create Start-up and generate ideas, the government that supports the Spin-offs financially, and the industry that can assimilate the new innovative products, methods and services are the future of innovation as wrote (Nacu and Avasilca, 2015).

An analysis of the situation regarding the level of development of the innovative activities within the studied enterprises will involve the specification and validation of dependency models between the resolute variables of the innovation activity and certain factorial variables, which are in fact elements of resources for the innovation activities. The associated comparison of innovation variables and those that come to ensure the enterprise's innovation environment will be used. In this case, we will use the correlation and the Student test (T-test statistic) to characterise the dependence between the variables of the sample of studied enterprises. In a later phase, to describe the interdependence between the resulting and the factorial variables that exert some influence on the level of innovation within the studied enterprises, we intend to address the interdependencies established between the variables in which innovation is expressed (resulting variables), and a series of factorial variables (Table 4).

Table 4. The variables used to characterise the innovative process in the enterprise

\begin{tabular}{lll}
\hline \# & Variables & Categories of innovation \\
\hline V8_TO & V8_TO & Turnover \\
q8_L & V8_E & The total number of employees in the enterprise \\
V9_HE & V9_HE & Share of employees with higher education \\
V10_1 & V10_1 & Implementation of a new or significantly changed corporate strategy \\
V10_2 & V10_2 & Implementing a new management technique within the company \\
V10_3 & V10_3 & Implement the significant changes to the organisational structure \\
V10_4 & V10_4 & Implementing changes to concepts or marketing strategies \\
V10_avg & V10_avg & Significant changes in process innovation \\
V14_1 & V14_1 & It introduced innovation in the production of goods and services. \\
V14_2 & V14_2 & Significantly improved production of goods and services \\
V14_3 & V14_3 & Has significantly improved the production process \\
V14 & V14 & Has applied Innovations (INNO) \\
V22_1 & V22_1 & After the introduction of innovations, the turnover was stable. \\
V22_2 & V22_2 & After the introduction of innovations, the turnover increased by no less than 10\% \\
V22_3 & V22_3 & After the introduction of innovations, the turnover decreased by no less than 10\% \\
V22 & V22 & Modifications in turnover \\
V23_1 & V23_1 & New business practices in the process of organisational procedures \\
V23_2 & V23_2 & New ways of organising work and decision making \\
V23_3 & V23_3 & New methods of organising external relations with other firms or government agencies \\
V23 & V23 & Process Innovations (INNO) \\
\hline Source:
\end{tabular}


To verify the relations established between various variables that can be characterised by the general situation of the enterprise, we initially intend to estimate the link between some quantitative aspects of the result of the economic activity expressed in terms of turnover (CA), and the factorial variables, which represents one of the essential factors of production - the number of employees $(\mathrm{L})$ and the quality of the labour force, the latter being expressed by the share of the employees with higher education $(\mathrm{HL})$. Thus, the relationship specified in this case will take the form in Table 8. Estimation equation:

$$
L O G\left(V 8 \_T O\right)=C(1) * V 8 \_E+C(2) * T R \_H L+C(3)
$$

Considering the significant differences between the correlated variables, a logarithm of the resulting variable (TO) was performed. The results of the estimation of the regression model in Table 5.

Table 5. The results of the regression model estimation preparing by authors

\begin{tabular}{|c|c|c|c|c|}
\hline \multicolumn{5}{|c|}{$\begin{array}{l}\text { Dependent Variable: LOG (V8_TO) } \\
\text { Method: LeastSquares } \\
\text { Sample (adjusted): } 151 \\
\text { Included observations: } 30 \text { after adjustments }\end{array}$} \\
\hline Variable & Coefficient & Std.Error & t-Statistic & Prob. \\
\hline V8_E & 0.014342 & 0.003196 & 4.487472 & 0.0001 \\
\hline $\mathrm{V} 9 \mathrm{HE}$ & 2.808492 & 0.708558 & 3.963672 & 0.0005 \\
\hline $\mathrm{C}$ & 12.61065 & 0.498237 & 25.31054 & 0.0000 \\
\hline R-Square & 0.639172 & \multicolumn{2}{|c|}{ Dependent mean var } & 15.15561 \\
\hline R-Square Adjust & 0.612444 & \multicolumn{2}{|c|}{ S.D. dependent var } & 1.587030 \\
\hline S.E. of regression & 0.987990 & \multicolumn{2}{|c|}{ Akaikeinfocriter. } & 2.908351 \\
\hline Squared residual sum & 26.35535 & \multicolumn{2}{|c|}{ Schwarz criteria. } & 3.048471 \\
\hline Probability log & -40.62526 & \multicolumn{2}{|c|}{ Hannan-Quinn criteria. } & 2.953177 \\
\hline F-statistic & 23.91391 & \multirow{2}{*}{\multicolumn{2}{|c|}{ Durbin-Watson stat }} & 1.865910 \\
\hline Prob (F-statistic) & 0.000001 & & & \\
\hline
\end{tabular}

Source: based on own calculation of authors

By substituting in the regression equation, the coefficients obtained from the estimation we get the relation. Substituted Coefficients:

$$
\text { LOG }\left(V 8_{-} T O\right)=0.0143424937366 * V 8_{-} E+2.80849150824 * V 9_{-} H E+12.6106469376
$$

Therefore, an observation of the indicators of the quality of the estimators and the model, in general, denotes the sufficiently high quality, with enough high significance for guaranteeing the results. In the circumstances described, the quality of the workforce, given by the proportion of employees with higher education, influences to a greater extent the results of the economic activity compared to the number of employees, and the variation of both factorial variables determines about $64 \%$ of the turnover variation (LOG (V8_TO). It is observed that Fisher statistics is relatively consistent and significant at the same time. The test Durbin-Watson (DW) indicates a value close to 2, which speaks errors about uncorrelated. The results of adjustment can be captured quite suggestive by through graphic representation.

In this case, deduce a valid and sufficiently credible data situation regarding the general characteristics of the companies involved in the study, which leads to increased chances for a similar validity of the information on the innovative activities supported by the investigated companies. Finally, to achieve a ranking of factors with the most significant influence on innovation. In this case, it will deduce an aggregate indicator, which will synthetically express all the variables representing the innovative activity of the studied 
I., Ubreziova, A., Diacikova, O., Sokil, S. Apostol. Innovation Ecosystems for the Moldovan Small and Medium-Sized Enterprises

enterprises. In this respect, a so-called innovation index (I_INNO) was determined, calculated as a general average of the specific standards of the variables expressing the innovation activity.

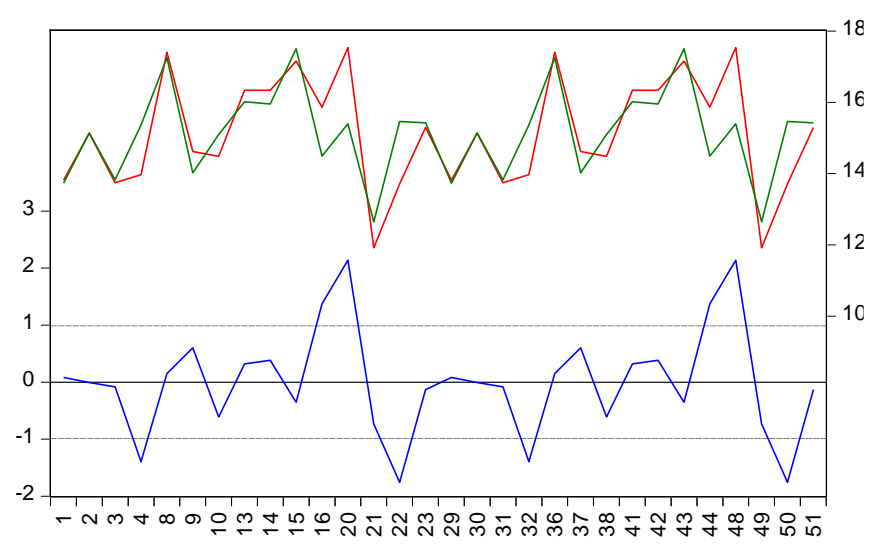

- Residual — Actual — Fitted

Figure 4. Empirical and adjusted values based on the presented model and model errors

Source: own processing by authors

In addition to the variables previously treated, we try to include in the model a variable representing the effects of innovative turnover activity (V22). The estimated relationship thus has the form:

$I \_I N N O=C(1) * V 10 \_A V G+C(2) * V 14 \_A V G+C(3) * V 22 \_A V G+C(4) * V 23 \_A V G+$ $C(5) * V 9_{-} H E+C$

After the data processing in the EViews environment, the model parameters estimators were obtained, entirely consistent, but also higher quality parameters, which validates the developed model (Table 6).

Table 6. The results of evaluating the factors with the most significant influence on innovation Dependent variable: I_INNO

\begin{tabular}{|c|c|c|c|c|}
\hline Method: Least Squares & \multicolumn{4}{|c|}{ Sample (adjusted): 751 Included observations: 25 after adjustments } \\
\hline Variable & Coefficient & Std.Error & t-Statistic & Prob. \\
\hline V10_AVG & 0.052223 & 0.036893 & 1.415537 & 0.01731 \\
\hline V14_AVG & 0.630732 & 0.045598 & 13.83250 & 0.00000 \\
\hline V22_AVG & 0.070425 & 0.044447 & 1.584465 & 0.01296 \\
\hline V23_AVG & 0.357064 & 0.023124 & 15.44098 & 0.00000 \\
\hline V9_HE & 0.004919 & 0.036873 & 0.133413 & 0.08953 \\
\hline C & -0.213305 & 0.071826 & -2.969745 & 0.00079 \\
\hline R-Square & 0.991606 & \multicolumn{2}{|c|}{ Dependent mean var } & 1.673360 \\
\hline R-Square Adjust & 0.989398 & \multicolumn{2}{|c|}{ S.D. dependent var } & 0.308828 \\
\hline S.E. of regression & 0.031799 & \multicolumn{2}{|c|}{ Akaikeinfocriter. } & -3.853173 \\
\hline Squared residual sum & 0.019213 & \multicolumn{2}{|c|}{ Schwarz criteria. } & -3.560642 \\
\hline Probability log & 54.16466 & \multicolumn{2}{|c|}{ Hannan-Quinn criteria. } & -3.772037 \\
\hline F-statistic & 448.9257 & \multicolumn{2}{|c|}{ Durbin-Watson stat } & 1.910946 \\
\hline Prob (F-statistic) & 0.000001 & & & \\
\hline
\end{tabular}

Source: own processing by authors 
l., Ubreziova, A., Diacikova, O., Sokil, S. Apostol. Innovation Ecosystems for the Moldovan Small and Medium-Sized Enterprises

By substituting the estimators of the regression coefficients with the values we obtain. Substituted Coefficients:

$$
\begin{aligned}
& I_{I N N O}=0.052 * V 10_{A V G}+0.631 * V 14_{A V G}+0.07 * V 22_{A V G}+0.357 * V 23_{A V G}+0.005 * \\
& V 9 \_H E-0.213
\end{aligned}
$$

Therefore, as expected, the most significant contribution to the formation of the so-called innovation index has been exercised by the indicators that, in our case, qualify innovation activity directly - V14 and V23. They also contribute to a more significant variation in the innovation index, that changing with a popular point of variable V14 leads to an index change of 0.63 popular I_INNO points. In comparison, the same shift in process innovation leads to modifying the result by about 0.36 popular points.

Conclusions. The conclusions should be logically consistent with the title and purpose of the article, thorough, contain a comparison of the results with the analogues, recommendations for their implementation. It is advisable to give a clear vision of the prospects for further research in this area. There are:

1. Revision of the system of statistical indicators and surveys, elaboration of the methodology and implementation of the indicators regarding the innovation statistics according to the requirements of the European Union and OECD. Implementation of innovative culture within the enterprises, creating a controlling model to develop and implement creative activities.

2. Creating of funding organisations, national innovation funds, and innovation supporting policies.

3. At the firm level, managers should increase the number of employees with higher education for innovation purposes, orient their expenses on research and development and creating own innovation techniques rather than buying them, direct work with university students, in the form of mentoring, pieces of training, traineeships, initiating joint research \& development projects.

Author Contributions: conceptualisation, I.U,O.S., S.A. and A.D.; methodology, I.U. and S.A.; software, S.A.; validation, I.U., O.S. and S.A.; formal analysis, A.D.; investigation, I.U.; resources, O.S. and S.A.; data curation, S.A.; writing —original draft preparation, I.U. and O.S.; writing—review and editing, I.U., S.A. and O.S; visualisation, A.D.; supervision, I.U. and S.A.; project administration, I.U., O.S. and A.D.

Funding: This paper is an outcome of the KEGA project 005SPU-4/2019 Theory and Practice of the International Management and Entrepreneurship in Multicultural Environment.

\section{References}

Basso, A. (2018). Startup Innovation Ecosystems in Southern Europe, European Commission, Brussels, JRC113872. pp.4-6. Cernei, G. (2011). National Innovation Strategy of Moldova 2012-2020. Retrieved from https://slideplayer.com/slide/7415384/ Cherroun, R. (2014). Product innovation and the competitive advantage. European Scientific Journal, 1, special edition, 140-157. Chladkova, H., Formankova, S. (2016). Strategy for SMEs in the area of primary agricultural production. Agricultural Economics, 62(9), 395-406. [Google Scholar] [CrossRef]
Disruptive and sustaining innovation.
(2018). Retrieved from https://www2.deloitte.com/il/en/pages/innovation/article/disruptive vs sustaining.html

European Comission (EC) (2006). Green paper on innovation. Retrieved from
https://europa.eu/documents/comm/green_papers/pdf/com2006 105 en.pdf

Fila, M., Kucera, J. (2015). Sucasny stav inovacnej vykonnosti Slovenska a slovenskych MSP. Produktivita a inovacie, 16 (2), 25 30. [Google Scholar]

Halasi, D., Schwarcz, P., Mura, L., \& Rohacikova, O. (2019). The impact of EU support resources on business success of familyowned businesses. Potravinarstvo Slovak Journal of Food Sciences, 13(1), 846-853. [Google Scholar] [CrossRef]

Jackson, D. J. (2019). What is an innovation ecosystem? National Science Foundation. 1(2). [Google Scholar]

Janoskova, M., Palascakova. D. (2018). Corporate social responsibility as a strategic goal in business: A case study.Corporate Social Responsibility (CSR): Practices, Issues and Global Perspectives. New York: Nova Science Publishers.

Jiao, H., Zhou, J., Gao, T., \& Liu, X. (2016). The more interactions the better? The moderating effect of the interaction between local producers and users of knowledge on the relationship between R\&D investment and regional innovation systems. Technological Forecasting and Social Change, 110, 13-20. [Google Scholar] [CrossRef] 
l., Ubreziova, A., Diacikova, O., Sokil, S. Apostol. Innovation Ecosystems for the Moldovan Small and Medium-Sized Enterprises

Kljucnikov, A., Civelek, M., Krajcik, V., \& Kmeco, L. (2020). Innovations in Tourism Marketing: Sharing Economy Platform. Marketing and Management of Innovations, 1, 11-25. [Google Scholar] [CrossRef]

Koellinger, P. (2008). Why are some entrepreneurs more innovative than others? Small Business Economics, 31 (1), 21-37. [Google Scholar] [CrossRef]

Madzik, P. (2019). Capture and evaluation of innovative ideas in early stages of product development. The TQM Journal, 31(6). 908-927. [Google Scholar] [CrossRef]

McGrath, R. G. (2012). A brief history of inventing innovation. Hanvard Business Review. Retrieved from https://hbr.org/2012/10/abrief-history-of-inventing-innovation

Mihalcova, B., Gallo, P., \& Lukac., J. (2020). Management of Innovations in Finance Education: Cluster Analysis for OECD Countries. Marketing and Management of Innovations, 1, 235-244. [Google Scholar] [CrossRef]

Mura, L. (2017). Current situation in Family Businesses. Managerial trends in the development of enterprises in globalisation era. Nitra: Slovak University of Agriculture in Nitra, 178-185

Nacu, C.M., Avasilca, S. (2015). A Model of Technological Innovation Process. Managing Intellectual Capital Innovation for Sustainable and Inclusive Society. pp.1783-1790

Obtulovic, P. (2004). Biostatistika (Biostatistics). Nitra, SUA

OECD. (2005). The Measurement of Scientific and Technological Activities. Guidelines for Collecting and Interpreting Innovation Data: Oslo Manual. $3^{\text {rd }}$ ed. Retrieved from http://www. oecd.org/science/inno/2367614.pdf

Pitekova, J., \& Vrablikova,M. (2019). Benchmarking of Slovak Regions in Terms of Start-UP Implementation and Creative Potential Indicators. Marketing and Management of Innovations, 4, 50-68. [Google Scholar] [CrossRef]

Reiljan, J., \& Paltser, I. (2015). The role of innovation policy in the national innovation system: the case of Estonia. Trames: A Journal of the Humanities and Social Sciences, 19(3), 249. [Google Scholar] [CrossRef]

Schwab, K. (2018). WORLD ECONOMIC FORUM. The Global Competitiveness Report. Retrieved from http://www.cdi.org.pe/pdf/IGC/2018/The_Global_Competitiveness_Report_2018.pdf

Selman, J. (2002). Leadership and innovation: Relating to circumstances and change. Innovation Journal, 7(3). 1-9. [Google Scholar] Stratan, A., Novac, A., \& Maier, L. (2018). Innovation Policy in the Republic of Moldova and Its Impact on the Business Development. [Google Scholar]

The Smart Guide to Service Innovation. (2014). Publications Office of the EU. Retrieved from https://op.europa.eu/en/publicationdetail/-/publication/0cc79ba3-98ec-478f-a0b1-3e4e37bbf7d7/language-en

Tohidi, H., \& Jabbari, M. M. (2012). The important of Innovation and its Crucial Role in Growth, Survival and Success of Organisations. Procedia Technology, 1, 535-538. [Google Scholar] [CrossRef]

Ubreziova, A., \& Horska, E. (2011). Perception and Approach towards Corporate Social Responsibility in SMEs: Case Study of Slovak and Czech Republic. In: PEFnet 2011 European Scientific Conference of Ph.D. Students, Brno, (pp. 1-7). [Google Scholar]

Ubreziova, I., Horska, E., Moravcíkova, K. \& Ubreziova, A. (2015). Globalisation and local alternative economic systems: the case of the Slovak Republic. In International scientific conference Rural Development 2017. [Google Scholar] [CrossRef]

Ubreziova, I., Wach, K. \& Horvathova, J. (2008). Entrepreneurship in small and medium-sized enterprises: Comparative study between Slovakia and Poland for the years 2001-2007. Agricultural Economic, 54(8), 358-366. [Google Scholar]

Івета Убрежіова

Професор, Католицький університет в Ружомберку, Словаччина

Оксана Сокіл

Словацький університет сільського господарства в Нітрі, Словаччина

Анна Діачікова

Ph.D., Католицький університет у Ружомберку, Словаччина

Стефан Апостол

Словацький університет сільського господарства в Нітрі, Словаччина

Інноваційна екосистема молдавських малих і середніх підприємств

Глобалізаційні процеси прискорюють розвиток інновацій та їх проникнення у всі сектори економіки. Інновацію відіграють ключову роль у задоволенні потреб споживачів, зростання прибутковості компанії та підвищенні ї конкурентоздатності на ринку. Авторами зазначено, що малі та середні підприємства поступово збільшують свою питому вагу у ВВП країни, а економічні показники ефективності їх функиіонування впливають на обсяги державного бюджету. У статі визначено, що не дивлячись на вагомий науковий доробок у даній сфері вченими не прийнято універсального методу оцінювання рівня інноваційного розвитку ні на рівні малих та середніх підприємств, ні на національному рівні. Метою статті є аналіз інноваційної діяльності молдавських малих та середніх підприємств, визначення фокторів, що впливають на їх інноваційний розвиток, а також дослідити інноваційної екосистеми на есфективність імплементації інновацій у підприємницьку діяльність. Вибірку досліджень сформовано на основі даних опитування електронною поштою 150 підприємців у період Липень-Серпень 2018 року. Авторами наголошено, що зростання рівня конкурентоспроможності малих та середніх підприємств залежить від ефективності впровадження 
I., Ubreziova, A., Diacikova, O., Sokil, S. Apostol. Innovation Ecosystems for the Moldovan Small and Medium-Sized Enterprises

інновацій у їх операційну діяльність. Результати дослідження свідчать, що найпоширенішим типом інновацій серед молдавських малих та середніх підприємств є інноваційна продукція. Визначено, що відсутність державного фрінансового стимулювання та відтік інтелектуального капіталу стримує розвиток інноваційної екосистеми в Молдові. Авторами наголошено на необхідності формування спільних інвестиційних фондів для підтримки інноваційного розвитку малих та середніх підприємств. При цьому менеджменту малих та середніх підприємств необхідно формувати конкурентоздатні умови праці, впроваджувати систему підвищення кваліфрікації працівників та стимулювати їх до саморозвитку.

Ключові слова: екосистема, підприємець, інновації, малі підприємства, середні підприємства.

Manuscript received: 10.01.2020

(C) The author(s) 2020. This article is published with open access at Sumy State University. 